\title{
Heamatological Studies on Sida Rhombifolia Ethanolic Leaf Extract of Micronor Induced Infertility in Female Rats
}

\author{
R.U. Ukpanukpong ${ }^{1 *}$, R.N. Uyabeme ${ }^{2}$, F.D. Adebiyi ${ }^{4}$, D.I. Basiru ${ }^{2}$, \\ B.S. Akinfesola ${ }^{2}$ and P.O. Aigbadumah ${ }^{3}$ \\ ${ }^{1}$ Department of Biochemistry, University of Calabar, Nigeria \\ ${ }^{2}$ Department of Chemical Sciences, Biochemistry Unit, Joseph Ayo Babalola \\ University, Osun State, Nigeria \\ ${ }^{3}$ Faculty of Medical Sciences, University of Jos, Nigeria \\ ${ }^{4}$ Department of Cell Biology and Genetics, University of Lagos, Nigeria \\ *Corresponding author
}

\section{A B S T R A C T}

\section{Keywords}

Body Weight Indices, Weight Blood cell Count, Red Blood Cell Counts Neutrophil and Mean Corpuscular Haemoglobin Concentration

Article Info

Accepted:

15 February 2019

Available Online:

10 March 2019
The research investigated the heamatological indices of Sida rhombifolia ethanolic leaf extract on micronor induced infertility in female rats. Sida rhombifolia is a shrub from the family of Malvaceae. Forty eight (48) female albino rats were randomly placed into six (6) study groups of eight (8) rats each and designated as; positive control group (PC) placed on distill water and normal feeds, micronor control group (MC) induced with micronor but not treated with Sida rhombifolia, Sida rhombifolia control group (SRC), (SRM1, SRM2, SRM3) induced with micronor and treated with ethanolic leaf extract of Sida rhombifolia at concentrations of $100 \mathrm{mg} / \mathrm{kg}, 200 \mathrm{mg} / \mathrm{kg}$ and $400 \mathrm{mg} / \mathrm{kg}$ body weight respectively for 14 days. Animals treated with $200 \mathrm{mg} / \mathrm{kg}$ and $400 \mathrm{mg} / \mathrm{kg}$ Sida rhombifolia ethanolic leaf extract showed a significant increase in white blood cell count activity and neutrophil concentration compared to the micronor control. There was also a significant increase $(\mathrm{P}<0.05)$ in the red blood cell counts of the extract treated group compared to the positive control. The extract was found to be non-toxic as seen in the extract fed normal rats. Findings depicts that ethanolic leaf extract of Sida rhombifolia possessed some hematopoitic effect on micronor induced infertility in female rats.

\section{Introduction}

Sida rhombifolia is a small erect woody, very variable annual or perennial under shrub about 1.5 meters high with rough branches and stellate hairs. Leaves are very variable in shape up to $5 \mathrm{~mm}$ by $18 \mathrm{~mm}$, short petioled, rhomboid-lanceolate to lanceolate, serrated towards the top, entire towards the base. Sida rhombifolia contains a variety of phytochemicals that has led to its use in many areas of medicine. Sida rhombifolia is demulcent, diaphoretic, diuretic, emollient, stomachic, tonic, sudorific, appetite and stimulant. It has significant medicinal applications for which it is cultivated 
throughout the world. Leaves and roots are used for piles, gonorrhea, Diuretic, aphrodisiac. Roots are held in great repute in treatment of rheumatism. Stems abound in mucilage and are employed as demulcents and emollients both for external and internal use. The herb is also useful in calculous troubles and as a febrifuge with pepper. Mucilage is used as an emollient and for scorpion sting. Australian aborigines use the herb to treat diarrhea. Leaves are smoked in Mexico and a tea is prepared in India for the stimulation it provides (Bhatt et al., 2003).

Sida rhombifolia is a perennial or sometimes annual plant in the family Malvaceae, it is native to the new world tropics and subtropics. Other common names include rhombus-leaved sida, paddy's Lucerne, jelly leaf and also somewhat confusingly as Cuban jute, Queensland hemp and Indian hemp (Although Sida rhombifolia is not related to either jute or hemp).Synonyms include Malva rhombifolia. It is used in Ayurvedic medicine, where it is known as Kurumthotti. This is another species native to India, Sida cordifolia. The stems are erect to sprawling and branched, growing 50 to 120 centimeters in height, with the lower sections being woody. The dark green, diamond-shaped leaves are arranged alternately along the stem, 4 to 8 centimeters long, with petioles that are less than a third of the length of the leaves. They are paler below, with short, grayish hairs. The apical half of the leaves has toothed or serrated margins while the remainder of the leaves is untoothed. The petioles have small spiny stipules at their bases (Kirtikar and Basu, 2001).

The moderately delicate flowers occur singly on flower stalks that arise from the area between the stems and leaf petioles. They consist of five petals that are 4 to 8 millimeters long, creamy to orange-yellow in color, and may be somewhat reddish in the center. Each of the five overlapping petals is asymmetric, having a long lobe on one side. The stamens unite in a short column. The fruit is a ribbed capsule, which breaks up into 8 to 10 segments. The plant blooms throughout the year. It is usually confined to waste ground, such as roadsides and rocky areas, stock camps or rabbit warrens, but can be competitive in pasture, because of its unpalatability to livestock (Dukej, 2004).

The hot aqueous extract of dried aerial parts of Sida rhombifolia is used for snake bite in East Africa. The hot aqueous extract of entire plant of S. rhombifolia in Borneo is used as an abortifacient when it is taken orally by pregnant women. The hot aqueous extract of entire plant is used as an abortifacient on oral administration in pregnant women in Central Africa (Bhandary et al., 2005). In India, the decoction of entire plant of S. rhombifolia when given orally to human adults reduces rheumatic pain. The decoction is also mixed with equal proportion of cow's milk and taken every morning for about a week for the same purpose. The hot aqueous extract of the plant in Malaysia is used for irregular menses when taken orally by adult females (Zamora and Pola, 2002).

The decoction prepared from entire plant of $S$. rhombifolia in Mexico is used to treat head cold when applied externally (Amico, 2007). The hot aqueous extract of the entire plant in Mozambique is used for cough when given orally to both sexes of human adults. The roots and leaves in Honduras are used as poultice when applied externally on boils (Sahu, 2004). The hot aqueous extracts of the entire plant in India is used as an aphrodisiac and in treatment of fever and urinary diseases when given orally to adult humans. The infusion of dried leaf of S. rhombifolia in Central Africa is used for diabetes, chest pain and diarrhea on oral administration. The infusion of this plant is applied locally for the 
treatment of skin diseases and infected wounds.

The leaf juice of the plant in India has been in use for the treatment of spermatorrhea on oral administration. The leaf juice of this plant in Madagascar is applied externally in abscesses and the leaf is useful in treating menstrual pain in Argentina (Noumi and Yomi, 2001). The leaf and root infusions of the plant in Cameroon are given orally in dysentery and diarrhea whereas in Mozambique, these are applied externally as emollient. The decoction of leaf and root of this plant are given orally to facilitate child birth (Deka et al., 2003). The hot aqueous extracts of dried leaf and root of the plant in India are used to treat nervous diseases, heart diseases, burning sensation of the body and as aphrodisiac and tonic. The decoction of leaf and stem of $S$. rhombifolia in Guatemala is taken orally in urinary inflammation. In India the leaf juice mixed with sesame oil for the treatment of snake bite and the fresh leaf juice is given orally in spermatorrhoea. The fresh leaf juice in New Guinea has been in use for the treatment of diarrhea in children. The fresh plant juice in India, is taken orally to dissolve stones in urinary tract, while in Nepal, the plant juice is applied externally for boils (Burkill, 2006).

\section{Materials and Methods}

\section{Materials, equipments and chemicals}

Drug: Micronor (BAYER WEIMAR GmbH and Co.KG Germany/Allemagne), Ethanol (Fimlab), Centrifuge (Sorvall RC-5B super speed, England), spectrophotometer (Spectrum lab 22PC England). ELISA KITS were products of Randox Laboratories Limited (Antrim, United Kingdom BT294QY), Analytical weighing balance (AXIS, model: BT200, Gdansk, Poland).
The animal feed pallet was purchased from the Osogbo central market, Oshogbo, Osun State.

\section{Experimental animals}

Forty eight (48) adult female albino Wistar rats between 100-150g were purchased from a disease free stock of the Ladoke Akintola University of Technology Medical Laboratory Osogbo Osun State and used for the study. The animals were allowed to acclimatize for two weeks before the commencement of the experiment. The rats were randomly assigned on the basis of their weight into six study groups of eight (8) rats each.

Normal feed and clean running water were given to the rats ad libitum. They were kept in wooden cages of eight (8) rats per cage, placed in the well-ventilated animal house of Joseph Ayo Babalola University Ikeji Arakeji Osun State at normal temperature of $30-35^{\circ} \mathrm{C}$. The cages were cleaned regularly and the rats were treated according to the international guidelines for the care and use of laboratory animals (NIH, 2008).

\section{Plant materials and identification}

Fresh and healthy plants of Sida rhombifolia was obtained from the Federal University of Agriculture, Ijapo, Akure, Ondo State, Nigeria. The plant samples were taken to the Department of Botany, Obafemi Awolowo University, Ile-Ife for identification and authentication.

\section{Preparation of plant extract}

The Sida rhomibifolia plants were sorted out and thoroughly washed to get rid of sand, the leaves were detached from the entire plant and allowed to air dry properly under a shade for 2 weeks. The dried leaves were then grounded properly to powder with the use of 
an electric blender. The powdered form was stored in an air tight container and stored until needed.

\section{Extraction procedure}

About 100 grams of the powdered leaves was soaked in $400 \mathrm{ml} \mathrm{98 \%} \mathrm{ethanol-water} \mathrm{(1:1)} \mathrm{at}$ room temperature for 3 days after which the mixture was filtered with a Whatman filter paper (No. 1). The filtrate was allowed to dry at room temperature in stainless plates after which it was scraped out and kept in an air tight container. The dried extract was dissolved in water to make 100, 200 and $400 \mathrm{mg} / \mathrm{kg}$ and stored.

\section{Induction of infertility}

Infertility was induced by administering oral doses of $0.5 \mathrm{mg} / \mathrm{kg}$ of Micronor for 5 days. $15 \mathrm{mg}$ of the Micronor was dissolved in 250 $\mathrm{ml}$ of water and administered orally to the rats $1 \mathrm{ml} /$ day with the aid of cannula tubes. And then they were allowed to co-habit with male rats after which they were left for 30 days to ensure that they were infertile before further treatment.

\section{Experimental design}

The grouping and treatment given to the rats in each of the groups are as follows: Group 1; designated PC consisted of positive control rats (Normal female rats). Group 2; designated as MC consisted of Micronor Induced Control rats (Female rats administered Micronor only). Group 3; designated as SRC consisted of extract control rats (Female rats administered $200 \mathrm{mg} / \mathrm{kg}$ of Sida rhombifolia ethanolic leaf extract only).

Group 4; designated SRM1 consisted of Micronor induced female rats administered $100 \mathrm{mg} / \mathrm{kg}$ of Sida rhombifolia ethanolic leaf extract. Group 5: designated SRM2 consisted of Micronor induced female rats administered $200 \mathrm{mg} / \mathrm{kg}$ of Sida rhombifolia ethanolic leaf extract. Group 6; designated SRM3 consisted of Micronor induced female rats administered $400 \mathrm{mg} / \mathrm{kg}$ of Sida rhombifolia ethanolic leaf extract.

Sacrifice of the animals and blood collection

At the end of the experimental period, rats in each study group were fasted overnight and sacrificed under anesthesia by cardiac puncture, blood was dispensed into specific sterile bottles (plain bottle for hormonal and cholesterol assay, EDTA bottles for Hematological indices).

\section{Hematological analysis}

\section{Packed cell volume}

Method: Micro haematocrit (Baker and Silverton, 2003)

Materials: Capillary tube, Haematocrit centrifuge, Haematocrit reader, Plasticine.

Principle: Anticoagulant blood in a glass capillary of specified length, bore size and wall thickness is centrifuged at $12,000 \mathrm{rpm}$ for 5 minutes to obtain a constant packing of the red blood cells while the plasma remains above the cells.

Procedure: The capillary tube was filled with the mixed blood up to $3 / 4$ of its length, one of the ends of the capillary was sealed with plasticine. It was placed in the centrifuge and spun for $5 \mathrm{mins}$ at $12,000 \mathrm{rpm}$. It was then read on the hematocrit reader.

\section{Total white blood cell count}

This was determined using bulk dilution method of Ochei and Kolhatkar (2007). 


\section{Differential white cell count}

\section{Haemoglobin estimation}

Haemoglobin was determined using the method of (Baker and Silverton, 2003).

\section{Mean corpuscular hemoglobin concentration}

Principle: The mean corpuscular hemoglobin concentration is a measure of the concentration of hemoglobin in a given volume of packed cell blood cells. It is reported as part of standard complete blood count.

Method: It was calculated by dividing the hemoglobin by the hematocrit. Reference ranges for blood tests are 32 to $36 \mathrm{~g} / \mathrm{dl}$, or between 19.9 and $22.3 \mathrm{mmol} / \mathrm{l}$. It is this a mass or molar concentration.

\section{Statistical analysis}

The data were expressed as mean value \pm S.E.M (standard error of mean). All results were mean of 8 determinations and the statistical analysis was carried out using students' t-test. The values were considered at probability level of $\mathrm{P}<0.05$. All the values of $\mathrm{P}<0.05$ were considered statistically significant.

\section{Results and Discussion}

This experiment evaluated the effect of the ethanolic leaf extract of Sida rhombifolia on hematological parameters of micronorinduced infertile female albino Wistar rats.

Change in body weight is used as an assessment of the response of an individual to therapeutic drugs and as an indication of the adverse effect of the drug (Teo et al., 2012).
In this study, Sida rhombifolia had an increasing effect on the body weight in a dose dependent manner which may be associated with the fact that Sida rhombifolia has an appetizing effect on the rats and they fed better during the experiment as earlier suggested by (Adeneye and Agbaje, 2008), rats treated with varying concentrations of ethanolic leaf extract of Sida rhombifolia $(100, \quad 200$ and $400 \mathrm{mg} / \mathrm{kg})$ showed proportional increase in body weight. It could also be that Sida rhombifolia interferes with the lipid metabolism of experimental animals. However, it was generally observed that there was a relatively significant increase in the final body weight when compared to the initial.

Blood parameters are good indicators of physiological, pathological and nutritional state of an animal and changes in hematological parameters gives an insight to a pathological condition and explains the impact of therapeutic drug testing.

Various medicinal herbs or conventional drugs/chemicals adversely affect certain blood components (Messaudi et al., 2008). Haemolyticanaemia and thromocytopaenia is known to be induced by flavonoids from herbs (Logeswari et al., 2012).

Hematological indices considered in the experiment were White blood cell activity, Red blood cell count, Neutrophil concentration and Mean corpuscular hemoglobin concentration. In this study, a significant increase was observed in WBC activity and neutrophil concentration of SRM2 and SRM3 $(p<0.05)$ compared to the positive control.

This might be due to the participation of neutrophils and monocytes in the process of phagocytosis as scavengers for a wide variety of particulate material (Sireeratawong et al., 
2014). It might also be the result of repair processes of hemopoiesis as neutrophils are the first line of defense mechanism (Gangu et al., 2011) (Fig. 1-5).

Fig.1 A graph showing the Body weight of rats in various study groups

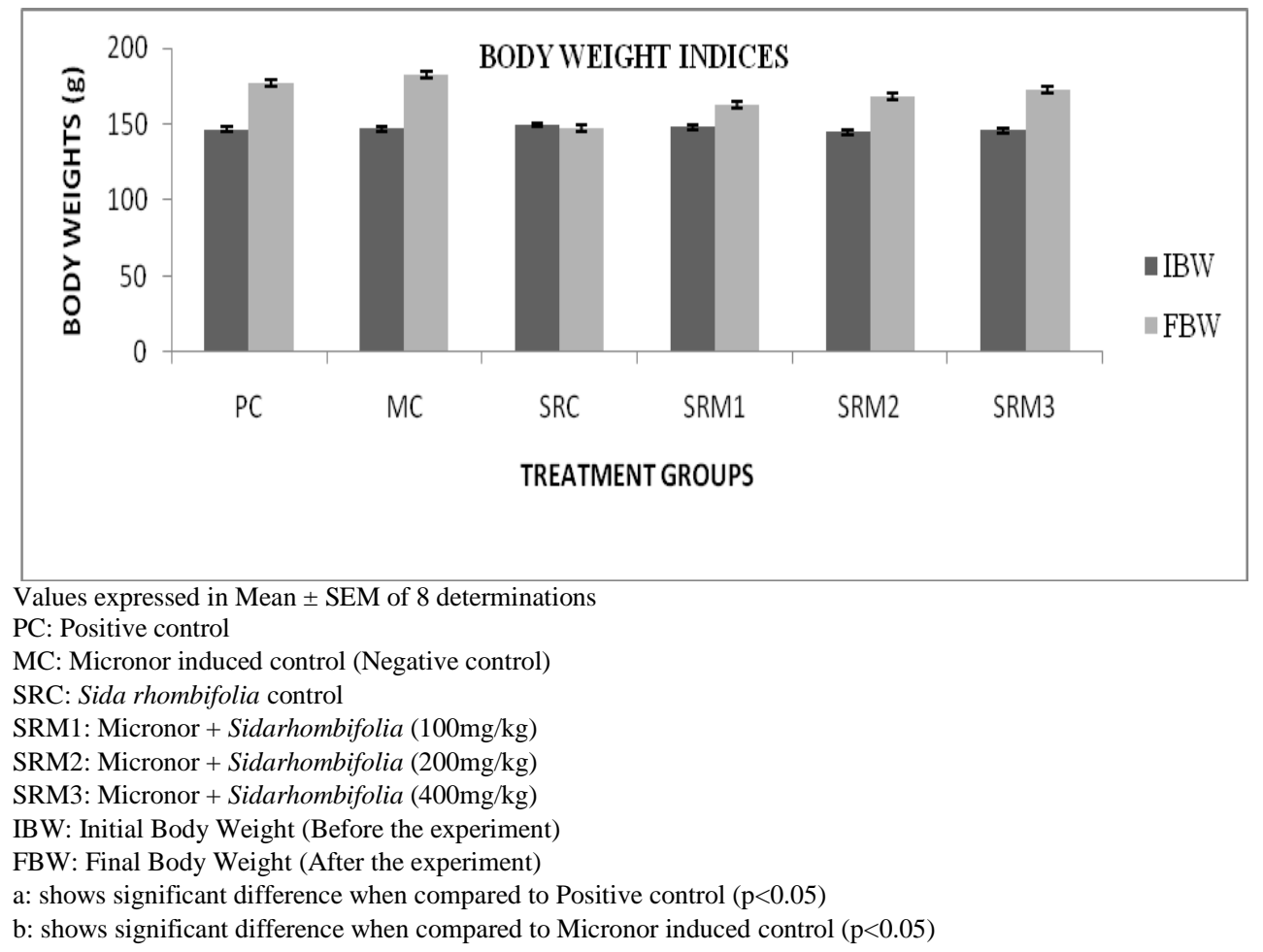

Fig.2 A graph showing the White blood cell activity of rats in various study groups

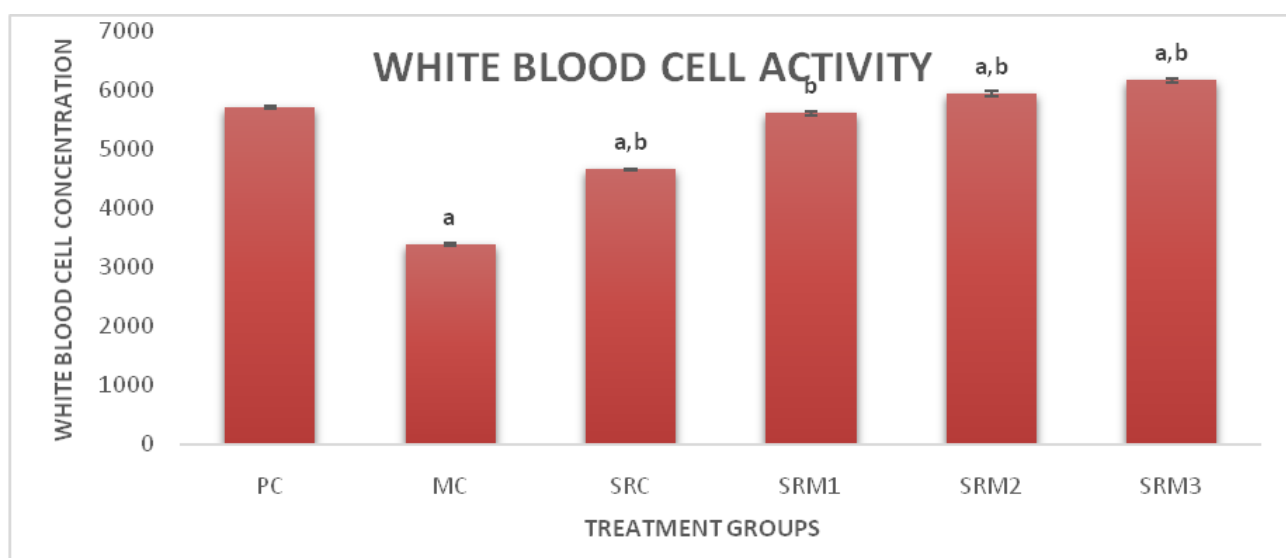

Values expressed in Mean \pm SEM of 8 determinations

PC: Positive control

MC: Micronor induced control (Negative control)

SRC: Sida rhombifolia control

SRM1: Micronor + Sida rhombifolia $(100 \mathrm{mg} / \mathrm{kg})$

SRM2: Micronor + Sida rhombifolia $(200 \mathrm{mg} / \mathrm{kg})$

SRM3: Micronor + Sida rhombifolia $(400 \mathrm{mg} / \mathrm{kg})$

a: shows significant difference when compared to Positive control $(\mathrm{p}<0.05)$

b: shows significant difference when compared to Micronor induced control $(\mathrm{p}<0.05)$ 
Fig.3 A graph showing the Red blood cell count of rats in various study groups

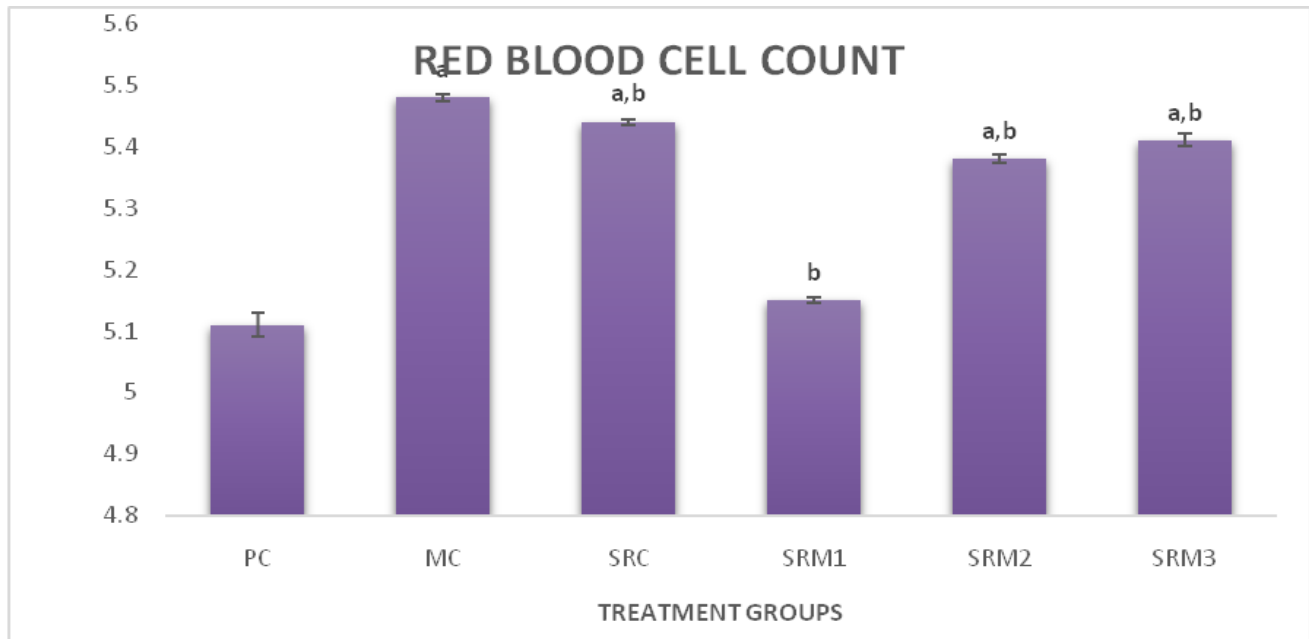

Values expressed in Mean \pm SEM of 8 determinations

PC: Positive control

MC: Micronor induced control (Negative control)

SRC: Sida rhombifolia control

SRM1: Micronor + Sida rhombifolia $(100 \mathrm{mg} / \mathrm{kg})$

SRM2: Micronor + Sida rhombifolia $(200 \mathrm{mg} / \mathrm{kg})$

SRM3: Micronor + Sida rhombifolia $(400 \mathrm{mg} / \mathrm{kg})$

a: shows significant difference when compared to Positive control $(\mathrm{p}<0.05)$

b: shows significant difference when compared to Micronor induced control $(\mathrm{p}<0.05)$

Fig.4 A graph showing the Neutrophil concentration of rats in various study groups

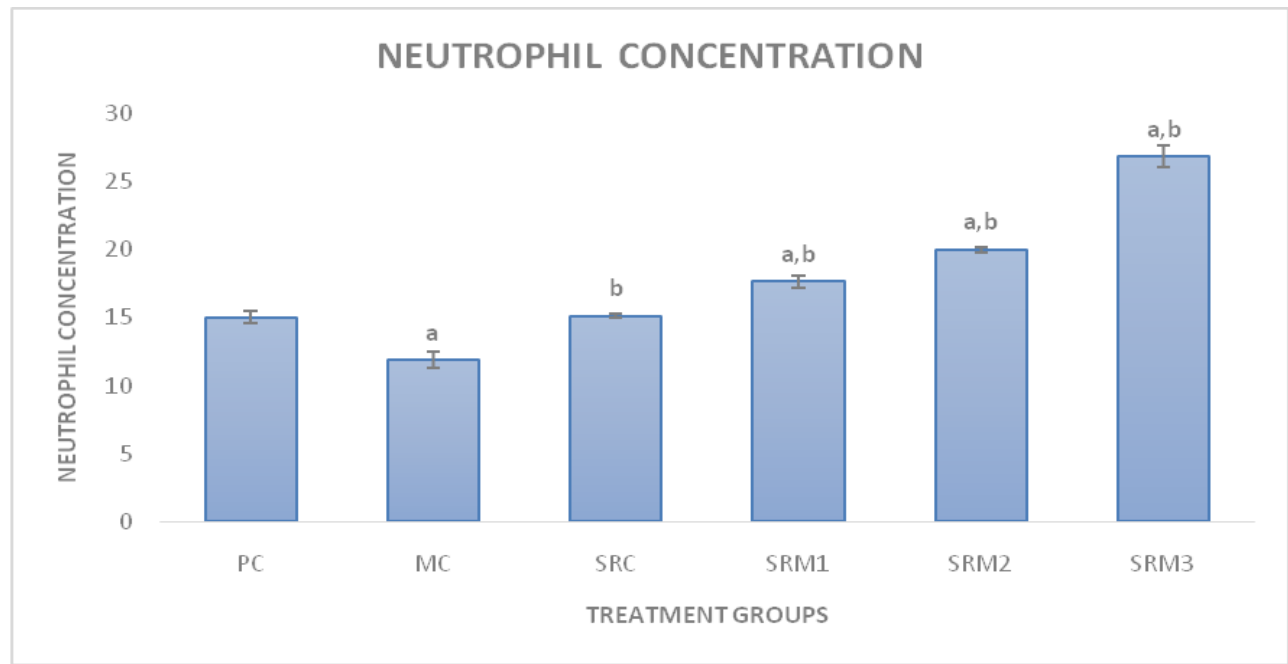

Values expressed in Mean \pm SEM of 8 determinations

PC: Positive control

MC: Micronor induced control (Negative control)

SRC: Sida rhombifolia control

SRM1: Micronor + Sida rhombifolia $(100 \mathrm{mg} / \mathrm{kg})$

SRM2: Micronor + Sida rhombifolia $(200 \mathrm{mg} / \mathrm{kg})$

SRM3: Micronor + Sida rhombifolia $(400 \mathrm{mg} / \mathrm{kg})$

a: shows significant difference when compared to Positive control $(\mathrm{p}<0.05)$

$\mathrm{b}$ : shows significant difference when compared to Micronor induced control $(\mathrm{p}<0.05)$ 
Fig.5 A graph showing the mean corpuscular hemoglobin concentration of rats in various study groups

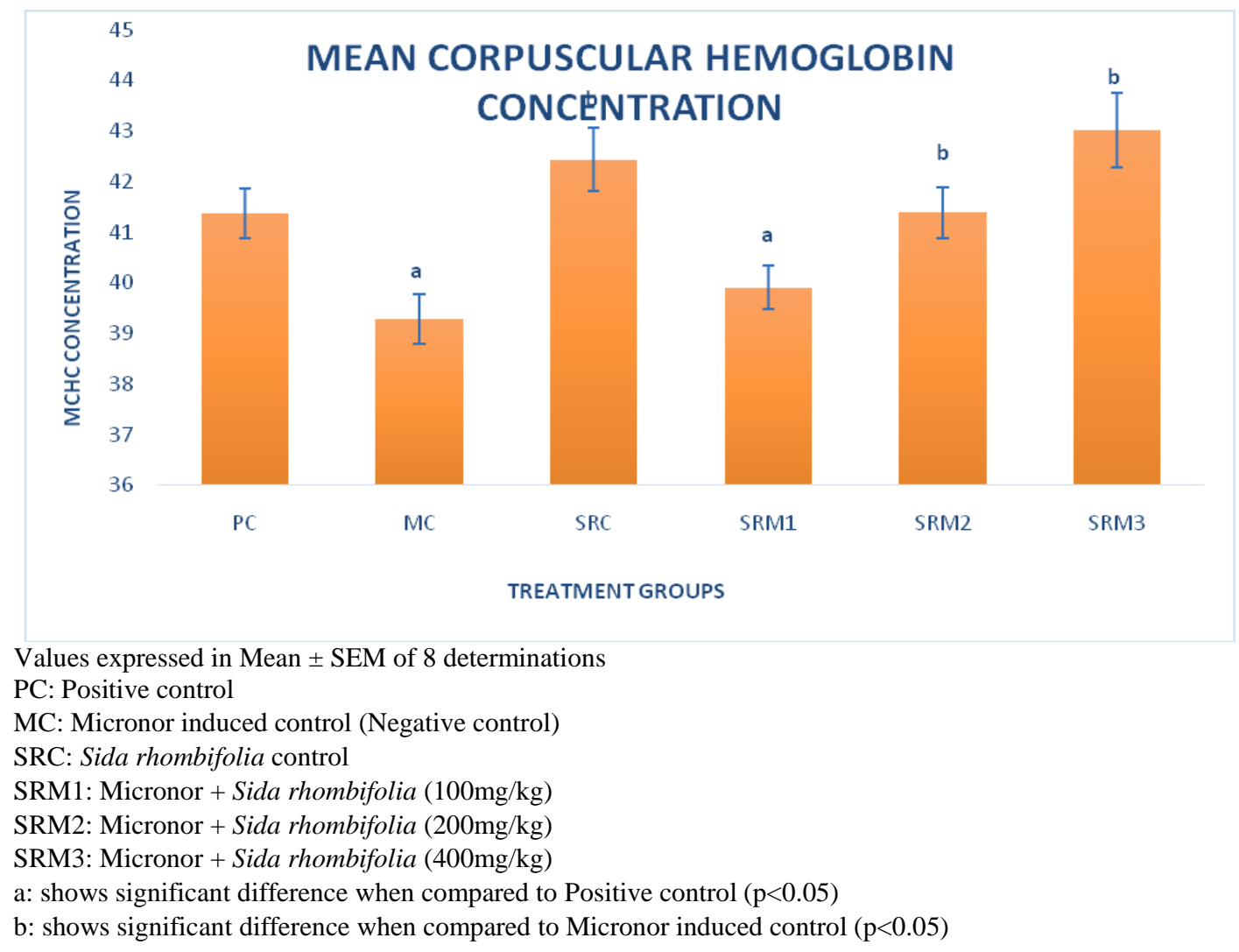

It was recorded in the study that there is a significant increase in mean corpuscular hemoglobin concentration of the treatment groups SRM2 and SRM3 compared to the micronor control group the result suggests that Sida rhombifolia may alleviate the anemic effects of micronor. Red blood cell count in the treatment groups SRM2 and SRM3 was also found to have significantly increased when compared to the positive control.

In conclusion, the biological effects of the ethanolic leaf extract of Sida rhombifolia obtained in this study supports the therapeutic use of Sida rhombifolia for treatment of endocrine related infertility and facilitation of fertility. The extract increased the levels of luteinizing hormone and estrogen of rats at low, moderate and high doses, possibly due to the presence of phyto-estrogens in the leaf of Sida rhombifolia.

\section{References}

Adeneye, A.A. and E.O. Agbaje, (2008). Pharmacological evaluation of oral hypoglycemic and antidiabetic effects of fresh leaves ethanol extract of Morinda lucida Benth. In normal and alloxan-induced diabetic rats. Afr. J. Biomed. Res., 11: 65-71.

Amico, A. (2007). Medicinal plant of Southern Zambesia, Fitoterapia, 48: 101-139.

Baker, R. and Silverton, T.(2003). Blood: Principles and Practice of Hematology. Lippincott Williams and Wilkins, 2(4): 183189.

Bhatt, D. J., Baxi, A. J and Parikh, A. R. (2003). Chemical investigations of the leaves of Sidar hombifolia Linn., Journal of Indian Chemical Society, 60: 98.

Burkill, I. H. (2006). Dictionary of the economic 
products of the Malay Penisula, Ministry of Agriculture and Co-operatives, Kuala, Lumpur, 155-189.

Deka, L, Majumdar, R. and Dutta, A. M. (2003). Some Ayurvedic important plants from district Kamrup, Ancient Science of Life, 3: 108-115.

Dukej, J A. (2004). Amazonian Ethnobotanical Dictionary, USA, 181.

Gangu, A. R., Prapulla, P., Anilkumar, C. H., Chamundeeswari, D. and Reddy, U. M. (2011). Free radical scavenging activity of the alcoholic extract of Sida rhombifolia roots in arthritic rats. Int. J. Res. Pharm. Chem. 1(3): 624-629.

Kirtikar, K.R and Basu, B.S. (2001). Indian medicinal plants, published by Mohen Basulalit, Allahabad. The ayurvedic pharmacopoeia of Indian, part 1, Department of AYUSH, ministry of Health and family welfare, Government of India, Vol-3: 24-46

Logeswari., P.T.A, Dineshkumar, V. and Prathap Kumar S.M. (). Efficacy of Sida rhombifolia root on cadmium chloride induced hematological alterations in rats. International Journal of Pharmacy and Technology. (2): 4741-4746.

Messaoudi, I., Hammouda, F., Heni, J. E., Baati, T., Said, K. and Kerkeni, A. (2010). Reversal of Cadmium-induced oxidative stress in rat erythrocytes by Selenium, Zinc or their combination. Exp. Toxicol. Pathol. 62(3): 281-288.

National Institute of Health (2008). Guide for the care and use of laboratory animals. 1(14): 82-86.

Noumi, E. and Yomi, A (2001). Medicinal plants used in for intestinal diseases in Mbalmaya region, central province, Cameroon: Fitoterapia, 72: 246-254.

Shibeshil, W., Makonnen, E., Debella, A. and Zerihun, L. (2006). Phytochemical, contraceptive efficacy and safety evaluations of the methanolic leaves extract of Achyranthesaspera L. in rats, Pharmacol., 3:217-224.

Ochei, R.and Kolhatkar,J.(2007). "InvivonearInfrared spectroscopy". Annual Review of Biomedical Engineering 6(2): 715-754.

Odebiyi, A. and Sofowora, A.E. (1978). Phytochemical Screening of Nigerian Medicinal Plants. Part III. Lloydia 41: 234246.

Teo, E.Y., Lew, P.S. and Feo, C.S. (2012): Public perception of obesity and bariatrics surgery in Singapore; A pilot study, Singapore Medical Journal, 53: 104-108

Sahu, TR. (2004). Less unknown uses of weed as medicinal plants, Ancient science of life, 3: 245-249

Sofowora, A. (1993). Medicinal plants and Traditional Medicine in Africa. $2^{\text {nd }} \mathrm{Ed}$. Spectrum Books Limited (Publisher), Ibadan, Nigeria, pp. 134-56.

Sireeratawong, S., Lertprasertsuke, N., Srisawat, U., Thuppia, A., Ngamjariyawat, A., Suwanlikhid, N. and Jaijoy, K. (2014). Acute and subchronic toxicity study of the water extract from root of Sida rhombifolia in rats, Afri. Journal Traditional Complimentary Alternative Medicine 24(7): 10-26.

Zamora-Martinez and Pola CNP. (2002). Medicinal plants used in some rural populations of Oaxaca, Puebla and Veracruz, Mexico, Journal of Ethnopharmacology, 35: 229-257.

\section{How to cite this article:}

Ukpanukpong, R.U., R.N. Uyabeme, F.D. Adebiyi, D.I. Basiru, B.S. Akinfesola and Aigbadumah, P.O. 2019. Heamatological Studies on Sida Rhombifolia Ethanolic Leaf Extract of Micronor Induced Infertility in Female Rats. Int.J.Curr.Microbiol.App.Sci. 8(03): 17511759. doi: https://doi.org/10.20546/ijcmas.2019.803.205 